\title{
純亜鉛融液／鋼界面における Fe-Zn系金属間化合物形成に及ぼす鋼中Siの影響
}

\author{
井上 純哉 ${ }^{1) *}$ ·三輪 哲嗣 ${ }^{1)}$. 小関 敏彦 ${ }^{1)}$
}

Effect of Si Content in Steel on Formation of Fe-Zn Intermetallic Compound Layer at Pure Zn Melt/Steel Interface

Junya Inoue, Satoshi Miwa and Toshihiko KoseKi

Synopsis : The effect of Si additions to the steel on the microstructure and growth kinetics of the Fe-Zn intermetallic compound (IMC) in the Fe/Zn diffusion couple with limited $\mathrm{Zn}$ supply was experimentally investigated. Three different steels with Si contents of less than $0.01 \mathrm{wt} \%, 0.44 \mathrm{wt} \%$, and $1.85 \mathrm{wt} \%$ were machined in cylindrical shape of $8 \mathrm{~mm} \varphi \times 6 \mathrm{mmh}$, and their bottom surfaces were polished chemically and mechanically to remove oxide and Si depletion layer. Pure Zn (99.99 \%) film was inserted between two steel cylinders, and enclosed in the steels in vacuum. The samples were heated at $450{ }^{\circ} \mathrm{C}$ for various holding time. Without $\mathrm{Si}$, an IMC layer composed of $\delta_{\mathrm{p}}, \delta_{\mathrm{k}}$, and $\Gamma$ phases were formed first, and it was later replaced by an IMC layer composed only of $\Gamma$ phase by the growth of $\delta_{\mathrm{k}}$ and $\Gamma$ phases. The addition of Si in steel suppresses the formation of $\Gamma$ phase as well as the growth rate of $\delta_{\mathrm{k}}$ phase, and IMC layers composed mainly of either $\delta_{\mathrm{p}}$ or $\delta_{\mathrm{k}}$ phases were successfully fabricated. Si was found to accumulate in $\alpha-\mathrm{Fe}$ at the $\alpha-\mathrm{Fe} / \delta_{\mathrm{k}}$ interface, which indicates that Si partitioning at the $\alpha-\mathrm{Fe} / \delta_{\mathrm{k}}$ interface is responsible for the instability of $\Gamma$ phase and slow supply of Fe from steel substrates. Finally, the fracture toughness and adhesion of IMC layer composed mainly of $\delta_{\mathrm{k}}$ phase were demonstrated inferior to those of $\delta_{\mathrm{p}}$ phase.

Key words: Fe-Zn intermetallic compounds; alloying elements; galvannealed coating.

\section{1. はじめに}

合金化溶融亜鉛めっき（Galvannealed, 以後 GA) 鋼板 は, 溶接性, 塗装性打よび耐食性に優れ, 自動車車体用の 防錆鋼板として幅広く用いられ，そのめっき皮膜は，と 相， $\delta_{1}$ 相， $\Gamma_{1}$ 相， Г相など複数の Fe-Zn 系金属間化合物相 (Intermetallic compound, 以後IMC) から構成されている。

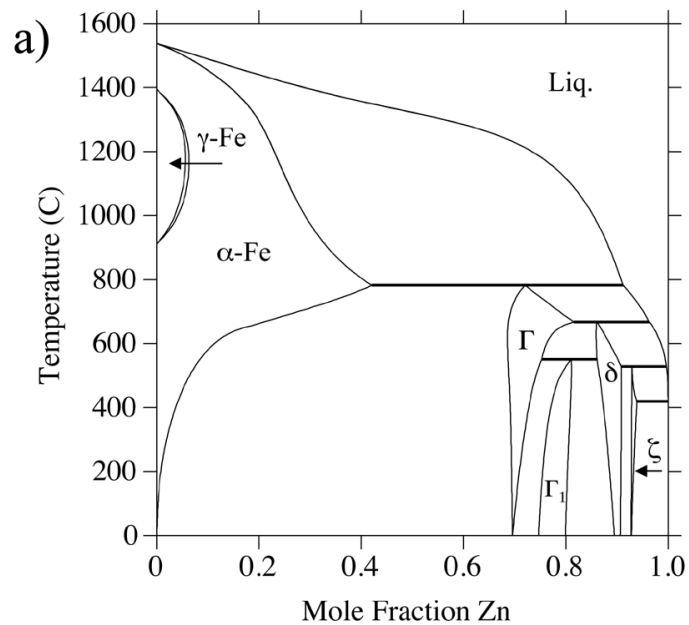

Fig.1にFe-Zn二元系状態図 ${ }^{1)}$ を示す。また， $\delta$ 相に関して は, より Zn 濃度が高い不規則相である $\delta_{\mathrm{p}}$ 相と, $\mathrm{Zn}$ 濃度の 低い規則相の $\delta_{k}$ 相に分類できることが明らかになってい $る^{2)}$ 。

前報ではめっき層の高強度化に不可欠と考えられる $\Gamma$ 相， $\delta_{\mathrm{k}}$ 相， $\delta_{\mathrm{p}}$ 相に着目し，これらの相で構成される $\mathrm{Fe}-\mathrm{Zn}$ 系IMC皮膜の破壞勒性を評価することで, $\Gamma$ 相の破壊勒

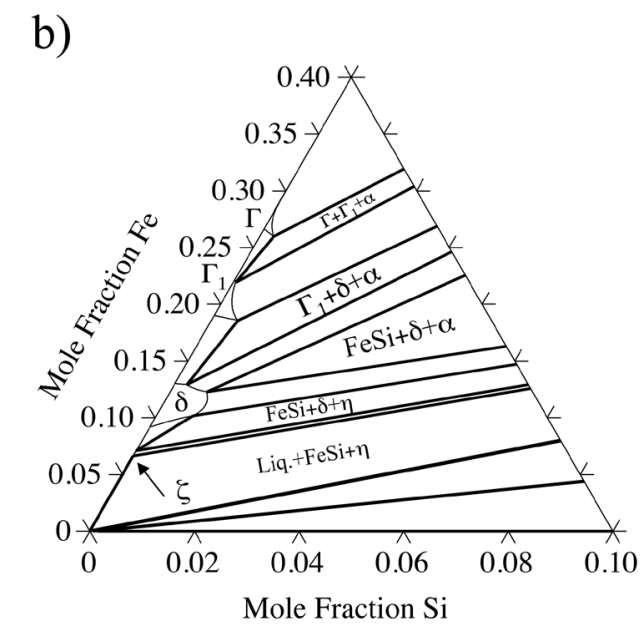

Fig. 1. (a) Fe-Zn Binary phase diagram ${ }^{1)}$ and (b) Fe-Si-Zn ternary phase diagram at $450{ }^{\circ} \mathrm{C}^{4)}$.

平成 25 年 7 月 29 日受付 平成 25 年 10 月 8 日受理 (Received on Jul. 29, 2013 ; Accepted on Oct. 8, 2013)

1) 東京大学大学院工学系研究科マテリアル工学専攻 (Department of Materials Engineering, The University of Tokyo, 7-3-1 Hongo, Bunkyo, Tokyo 113-8656)

* Corresponding author : E-mail : inoue@material.t.u-tokyo.ac.jp

DOI : http://dx.doi.org/10.2355/tetsutohagane.100.390 
性值は $\delta_{\mathrm{p}}$ 相と比較し低いことを明らかにし, さらに $\delta$ 相 の中でも $\delta_{\mathrm{k}}$ 相は $\delta_{\mathrm{p}}$ 相と比較して極めて破壊勒性が低い可

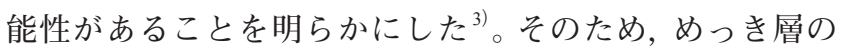
高強度化には $\delta_{\mathrm{p}}$ 相を主体とすることが有効と思われるが, $\mathrm{Fe}-\mathrm{Zn}$ 二元状態図を考えた場合， $\delta_{\mathrm{p}}$ 相単独ではフェライト 相と平衡にはなりえず, 鋼界面近傍には必ず $\Gamma$ 相や $\delta_{\mathrm{k}}$ 相 が形成すると考えられる。実際, 極低炭素鋼と純亜鉛の固 液拡散対を用いた前報では, 比較的短時間の等温保持では $\delta_{\mathrm{p}}$ 相が主相となる皮膜が形成されるものの, 界面には $\delta_{\mathrm{k}}$ 相や $\Gamma$ 相も形成されており, 特に $\delta_{k}$ 相成長の抑制は困難 であることが示唆されている ${ }^{3)}$ 。そこで本研究では, $\delta$ 相 がフェライト相と共存しうる Fe-Si-Zn三元系合金をモデル ケースとし (Fig.lb $)^{4)}$, 鋼への合金元素の添加による鋼界 面近傍に形成する $\delta_{\mathrm{k}}$ 相や $\Gamma$ 相の抑制効果を検討すること を目的とした。な打, 一般に鋼への Si添加は, 連続式溶融 亜鉛めっきラインでの焼鈍工程で $\mathrm{Si}$ が選択的に外部酸化 することで溶融亜鉛と母材との濡机性を低下させ溶融亜鉛 が被覆せずに母材が裸出する, いわゆる不めっき欠陥を生 じさせる。また, 鋼中のSi Si溶融亜鉛に浸漬した場合, 通 常形成されるめっき層より厚く凹凸のあるめっき層が形成 されることが知られている。このとき, 全反応鉄量は $\mathrm{Si}$ 量 が多くなるにつれて増加し，0.06-0.10 wt\% $\mathrm{Si}$ 付近において 反応の極大を示した後低下し，0.20-0.30 wt $\% \mathrm{Si}$ 付近に極小 を示すが ${ }^{5)}$ ささらに $\mathrm{Si}$ 量が多くなり $0.45 \mathrm{wt} \% \mathrm{Si}$ 付近に $2 つ$ めの極大を示し, 高 $\mathrm{Si}$ 量では再び低下すると報告されてい る ${ }^{6,7)}$ 。この鋼中の $\mathrm{Si}$ が Fe-Znの界面反応に及ぼす影響につ いては, 一般に, Siが 結晶の核生成に影響を及ぼすとす るモデルや ${ }^{8)}, \mathrm{FeSi}$ の影響9) などが提案されているが, いず れも亜鉛浴中に鋼試料を浸漬する Znの供給が過多な条件 に打いて確認される現象である。そこで本研究では, これ らの影響を回避した上で, 鋼への $\mathrm{Si}$ 添加が $\delta_{\mathrm{p}}$ 相， $\delta_{\mathrm{k}}$ 相， $\Gamma$ 相の形成過程へ及ぼす影響を明らかにすると共に, IMC被 膜に対する曲げ剥離特性の評価を行った。

\section{2. 実験方法}

$\mathrm{Fe}-\mathrm{Zn}$ 系 IMC皮膜の形成過程に対する鋼への Si添加の 影響について調査するため, $0.01 \mathrm{wt} \% \mathrm{Si}$ 以下，0.44 wt\% $\mathrm{Si}$, $1.85 \mathrm{wt} \% \mathrm{Si}$ の3 種類の鋼を用いた。用いた鋼の化学組成を Table 1 に示す。

鋼試料から $8 \mathrm{~mm} \phi \times 6 \mathrm{mmh}$ の円柱試料を切り出し, 加

Table 1. Chemical compositions of silicon containing steels (wt $\%$ ).

\begin{tabular}{cccccccccc}
\hline & $\mathrm{C}$ & $\mathrm{Si}$ & $\mathrm{Mn}$ & $\mathrm{P}$ & $\mathrm{S}$ & $\mathrm{Al}$ & $\mathrm{N}$ & $\mathrm{O}$ & $\mathrm{Ti}$ \\
\hline $0.01 \%>$ & 0.00 & $0.01>$ & 0.16 & - & - & 0.042 & - & 0.003 & 0.042 \\
$0.44 \%$ & 0.08 & 1.00 & 2.0 & 0.005 & 0.05 & 0.031 & 0.002 & 0.002 & - \\
$1.85 \%$ & 0.30 & 1.85 & 1.22 & 0.004 & 0.005 & 0.033 & 0.002 & 0.001 & - \\
\hline
\end{tabular}

工ひずみを除去する目的で焼鈍熱処理を行った。次いで, 焼鈍熱処理中に鋼試料表面に形成された酸化膜ならびに $\mathrm{Si}$ 欠乏層を研磨除去後, 接合面を機械的および化学的に

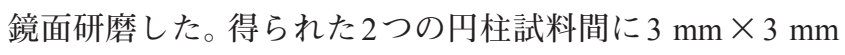
$\times 25 \mu \mathrm{m}$ 厚の純亜鉛箔 $(99.99 \%)$ を挟み, 熱間加工シミュ レーターを用いて $5 \times 10^{-1} \mathrm{~Pa}$ の真空中で試料全体を $5 \%$ 圧 下し，純亜鉛簿を鋼試料中に完全に密閉封入した（Fig.2）。 Fe-Zn系IMCの等温保持過程における成長を観察するた め, 更に真空中で試料全体を $40{ }^{\circ} \mathrm{C} / \mathrm{s}$ で急速加熱し, $450^{\circ} \mathrm{C}$ で任意の時間 (10 10000 秒) 等温保持後 $50^{\circ} \mathrm{C} / \mathrm{s}$ でガス急 冷した。これにより，熱処理中の鋼の表面酸化が抑制され， $\mathrm{Fe}$ と溶融亜鉛間で生じる固液反応に対する $\mathrm{Si}$ 添加の影響 が調查できると考えた。

鋼表面に形成された Fe-Zn 系IMC 相の同定には, 走査型 電子顕微鏡 (SEM) による組織観察, EBSPによる組織解析, EDSによる組成分析を行った。一般に， $\delta$ 相の組織形態は 皮膜表面側に形成される突起状組織と鋼側に形成される内 部組織が不明瞭な相からなり, 前者が $\delta_{\mathrm{p}}$ 相, 後者が $\delta_{\mathrm{k}}$ 相に 相当すると言われる ${ }^{9,10)}$ 。しかし, Kainuma and Ishidaが指 摘するように ${ }^{11)}$ ，それぞれの組織形態は成長過程の状況に より異なる。そこで本研究では, 前報 ${ }^{3)}$ と同様に化学組成 と組織形態の両面から総合的に判断し, 相の同定を行うこ ととした。

\section{3. 実験結果および考察}

\section{3・1 Fe-Zn系IMCの微細組織評価}

Fig.3に, $0.01 \mathrm{wt} \%>\mathrm{Si}$ 鋼の表面から等温保持 $10,30,300$, 1000，10000秒で形成された Fe-Zn 系IMC層の微細組織,
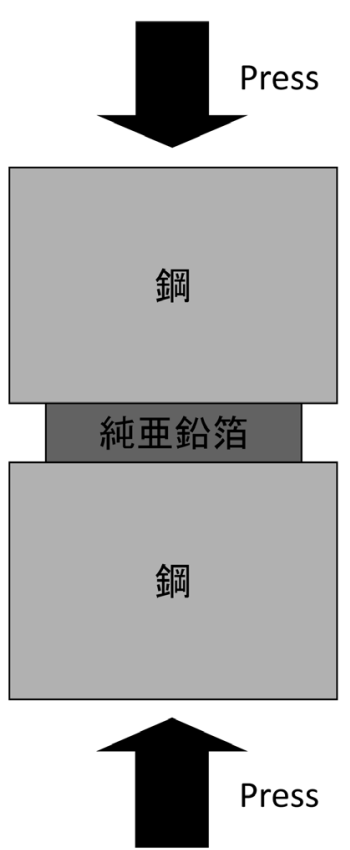

Fig. 2. Schematic showing experimental setup. 
EBSPによる組織解析の結果, EDSによる組成解析の結果 を示す。またFig.4に，1.85 wt\%Si鋼の表面から等温保持 10，60，300，10000秒で形成された Fe-Zn 系 IMC 層の微細 組織, EBSPによる組織解析の結果, EDSによる組成解析 の結果を示す。 $0.01 \mathrm{wt} \%>\mathrm{Si}$ 鋼の試料では, 等温保持 10 秒 の時点で試料中央の液相側より順に空隙を多数含む突起 状組織，その下層にはSEM像では形態が不明瞭であるが EBSP組織解析からは2層の粒径が異なる液相方向に長く 伸びた異方性の強い柱状晶組織が確認でき, 更にその下層 の鋼 / IMC界面近傍には別の微細な柱状晶組織が存在す る。 $\mathrm{Fe}$ 濃度は, 表層から第2 層まではほぼ一定であり， $\delta_{\mathrm{p}}$ 相に相当する濃度 ${ }^{11)}$ を示す一方で, 第 2 層から第 3 層の間 では僅かな濃度ギャップを伴い上昇し， $\delta_{\mathrm{k}}$ 相に相当する 濃度 ${ }^{11)}$ に達する。更に, 鋼 / IMC界面近傍に存在する層 では「相に相当する $\mathrm{Fe}$ 濃度まで急激に上昇している。こ れらの結果より, 表層と第2層では組織形態は異なるもの の共に $\delta_{\mathrm{p}}$ 相，第 3 層は $\delta_{\mathrm{k}}$ 相，第 4 層は $\Gamma$ 相であると判断し た。な打, EBSP解析により各層の結晶系の同定も行って
おり, 液相より 3 層は hexagonal構造, 鋼 / IMC界面近傍の 1 層はbcc構造と同定されているが，いずれの相も信頼值 (Confidence Index) が低いため, 微細組織の特徴と Fe濃度 の両面から相の判別を行っている。また, 状態図からは $\delta$ 相と $\Gamma$ 相の界面には $\Gamma_{1}$ 相の存在が予見されるが, 前報 ${ }^{3)}$ と 同様に短時間の等温保持では Fe 濃度と結晶構造からは明 確な $\Gamma_{1}$ 相の形成は確認できなかった。その後, 時間経過に 伴い $\Gamma$ 相と $\delta_{\mathrm{k}}$ 相が $\delta_{\mathrm{p}}$ 相側に成長し，等温保持 300 秒では $\delta_{\mathrm{p}}$ 相が完全に消滅し，IMC層は $\delta_{\mathrm{k}}$ 相と $\Gamma$ 相のみで構成さ れる。また, 前報 ${ }^{3)}$ と同様に等温保持 $10^{3}$ 秒以降では, $\delta_{\mathrm{k}}$ 相 中の $\Gamma$ 相との界面近傍付近からは， $\Gamma_{1}$ 相と考えられる fcc 構造を有する組織の形成も確認できた。その後, 時間経過 に伴い $\Gamma$ 相と $\Gamma_{1}$ 相が成長し, 最終的には $\Gamma$ 相単相組織へと 変化することが確認された。一方，1.85 wt\% $\mathrm{Si}$ 鋼では，等 温保持 10 秒では Feの純亜鉛融液への溶出は確認できるが $\mathrm{Fe}-\mathrm{Zn}$ 系 IMCの形成は確認できなかった。等温保持 60 秒で は $0.01 \mathrm{wt} \%>\mathrm{Si}$ 鋼の試料と同様に化学組成と組織解析の結 果から $\delta_{\mathrm{p}}$ 相と $\delta_{\mathrm{k}}$ 相の形成が確認できるものの, $\Gamma$ 相や $\Gamma_{1}$

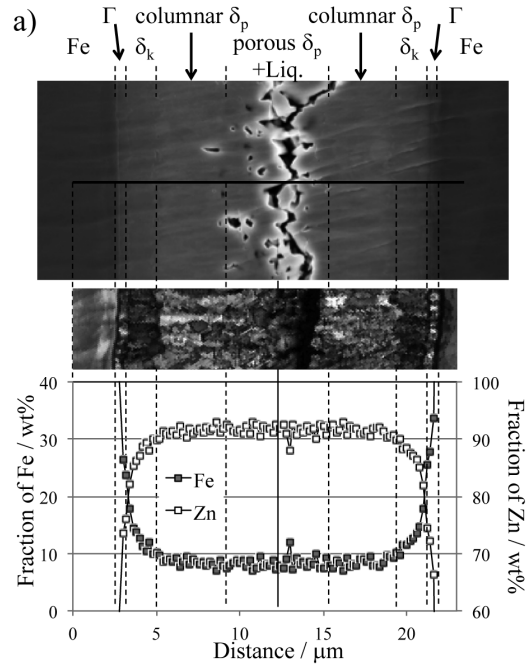

d) b)

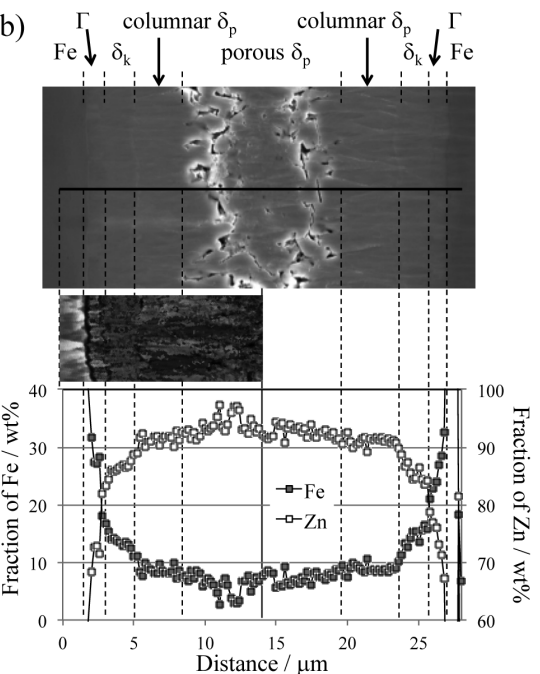

c)

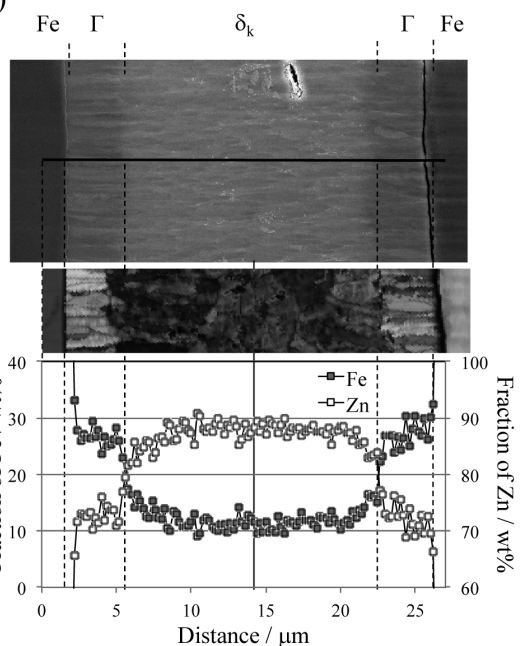

$\mathrm{Fe} \Gamma$

$\delta_{\mathrm{k}}\left(\Gamma_{1}\right)$

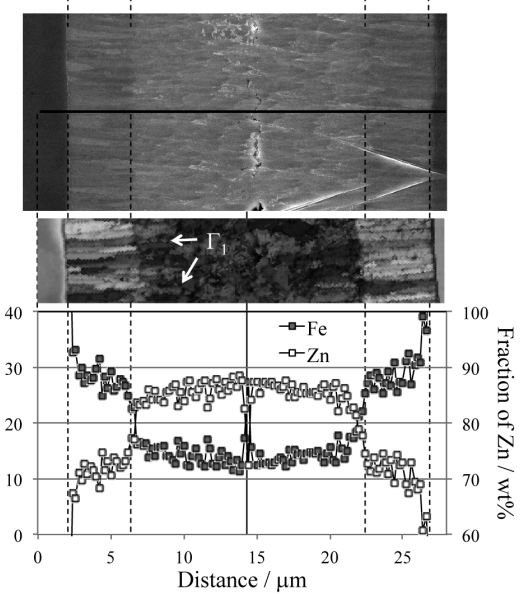

e)

e) $\mathrm{Fe} \quad \Gamma$

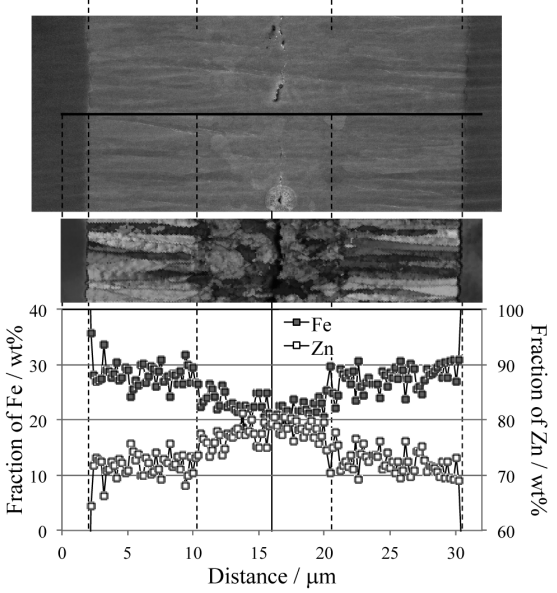

Fig. 3. Microstructure and chemical composition profile in the Fe-Zn IMC layer formed at the interface between 0.01 wt $\%>$ Si steel and $\mathrm{Zn}$ melt during the isothermal holding at $450{ }^{\circ} \mathrm{C}$ for a) $\left.\left.\left.10 \mathrm{~s}, \mathrm{~b}\right) 30 \mathrm{~s}, \mathrm{c}\right) 300 \mathrm{~s}, \mathrm{~d}\right) 1000 \mathrm{~s}$, and e) $10^{4} \mathrm{~s}$. 
相の形成は確認できなかった。その後, 保持時間の増加に 伴い界面近傍の $\delta_{\mathrm{k}}$ 相が成長するものの, その成長速度は $0.01 \mathrm{wt} \%<\mathrm{Si}$ 鋼と比較し極めて遅く, 等温保持 300 秒におい ても $\delta_{\mathrm{k}}$ 相は IMC 層の半分程度を占める程度である。また, この時点でも鋼/ IMC界面に $\Gamma$ 相や $\Gamma_{1}$ 相の形成は見られ ず, Fe-Zn 系 IMC 層は $\delta_{\mathrm{p}}$ 相と $\delta_{\mathrm{k}}$ 相から構成されている。そ の後，時間経過とともに $\delta_{\mathrm{k}}$ 相は成長し，保持時間 $10^{4}$ 秒ま で $\Gamma$ 相や $\Gamma_{1}$ 相の形成は確認できず, IMC層は $\delta_{\mathrm{k}}$ 相単相組 織となることが確認された。なお, EBSP解析の結果より, Siが添加された鋼においては鋼界面近傍と液相側の組織で は粒径が異なることが分かる。これは反応初期に液相から 形成された $\delta_{\mathrm{k}}$ 相と, 初期に形成された $\delta_{\mathrm{p}}$ 相に Feが供給さ れことで形成された $\delta_{\mathrm{k}}$ 相の違いと考えられるが, その詳 細は不明である。また, Fig.1bに示す状態図からも, Fe-Zn 系IMCにはSi は微量にしか固溶しないことが示されてい るが，いずれの試料においても EDS 解析では検出限界の問 題から Fe-Zn 系 IMC 層中には Si を検出できなかった。Fig.5 と Fig.6に, 鋼 $/ \mathrm{IMC}$ 界面から $\delta_{\mathrm{p}}$ 相 $/ \delta_{\mathrm{k}}$ 相界面までの距離
と, Fe- Zn 系 IMC 層への Feの供給量の時間変化をそれぞれ 示す。Fig.5 中の点線は, 鋼 / IMC界面から約 $12 \mu \mathrm{m}$ の位置 を示しており， $\delta_{\mathrm{p}}$ 相 $/ \delta_{\mathrm{k}}$ 相界面がこの距離に到達した時 点で $\delta_{\mathrm{p}}$ 相が消失する。また, Fig.6中の灰色の帯は, EDS 解 析により得られた $\delta_{\mathrm{p}}$ 相, $\delta_{\mathrm{k}}$ 相, $\Gamma$ 相の大凡の $\mathrm{Fe}$ の濃度範

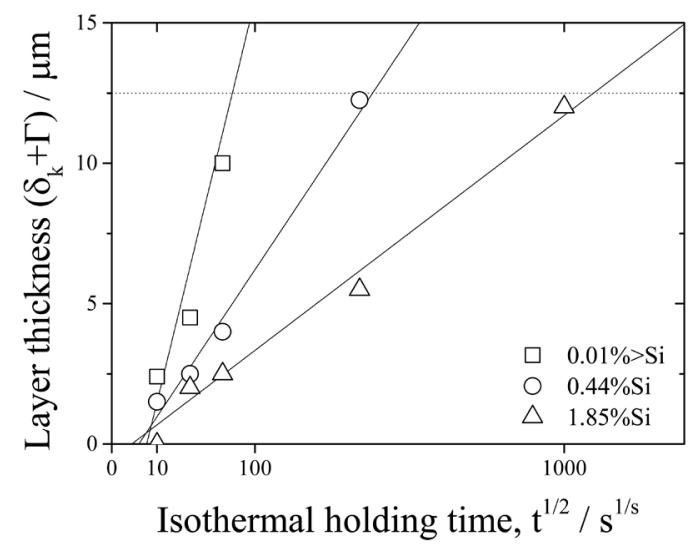

Fig. 5. Distance between $\alpha-F e / I M C$ interface and $\delta_{\mathrm{p}} / \delta_{\mathrm{k}}$ interface. a)

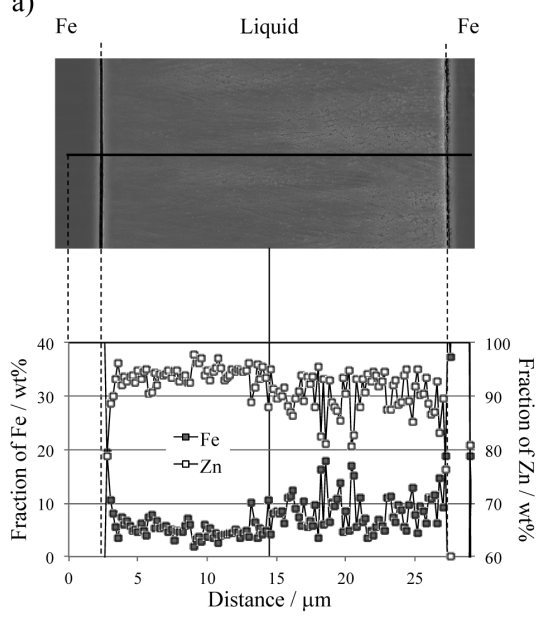

d)
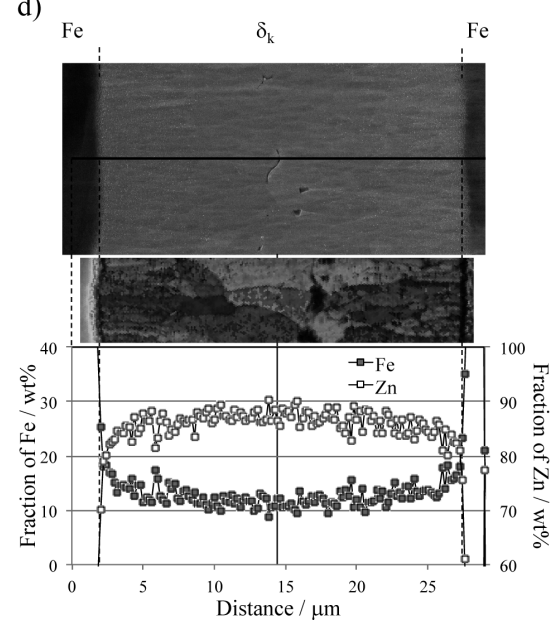

b)

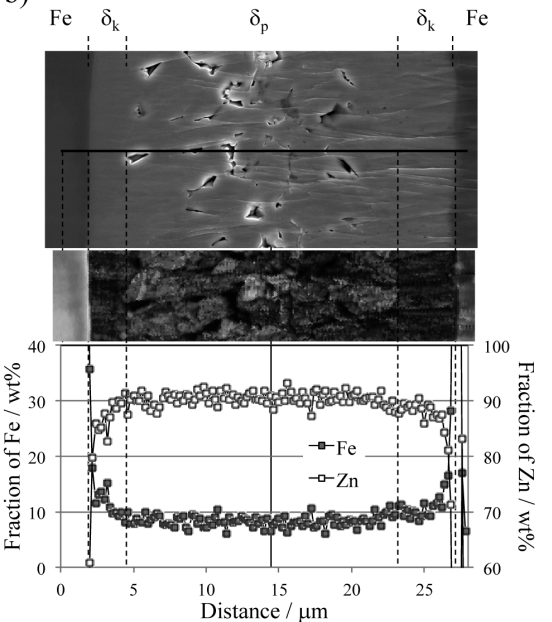

e) c)
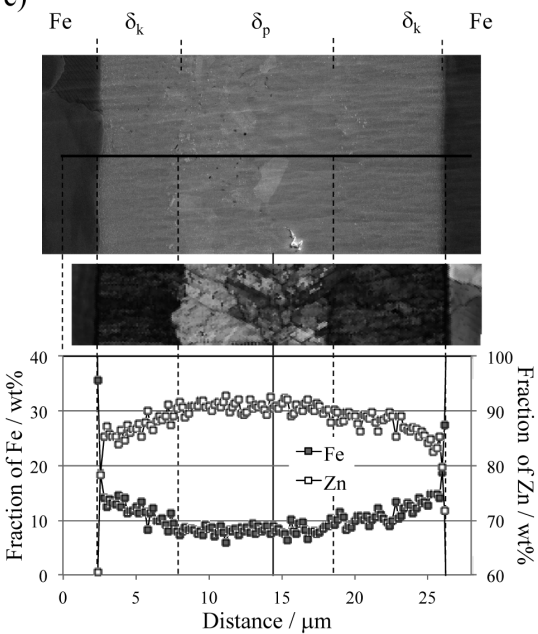

$\delta_{\mathrm{k}}$

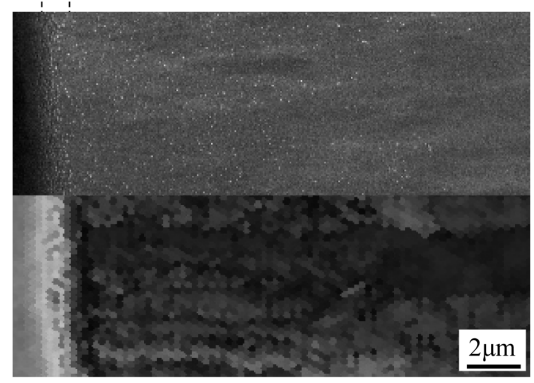

Fig. 4. Microstructure and chemical composition profile in the Fe-Zn IMC layer formed at the interface between $1.85 \mathrm{wt} \% \mathrm{Si}$ steel and $\mathrm{Zn}$ melt during the isothermal holding at $450{ }^{\circ} \mathrm{C}$ for a) $10 \mathrm{~s}$, b) $60 \mathrm{~s}$, c) $300 \mathrm{~s}$, and d) $10^{4} \mathrm{~s}$, and e) enlarged image of d) at the $\alpha-\mathrm{Fe} / \delta_{\mathrm{k}}$ interface. 
囲を示している。いずれの試料においても, 鋼/IMC界面 から $\delta_{\mathrm{p}}$ 相 $/ \delta_{\mathrm{k}}$ 相界面までの距離は, 極めて短い潜伏期間 の後, 保持時間の平方根に比例して増加している。一方, $\mathrm{Fe}$ の供給量は等温保持開始直後に急激に上昇し, $\mathrm{Si}$ を添加 していない鋼では $\delta_{\mathrm{k}}$ 相に, $\mathrm{Si}$ を添加した鋼では $\delta_{\mathrm{p}}$ 相に相 当する濃度に達するが, その後はやはり保持時間の平方根 に比例して増加している。また， $\delta_{\mathrm{p}}$ 相 $/ \delta_{\mathrm{k}}$ 相界面の移動速 度, IMC 層形成後の $\mathrm{Fe}$ の供給量は $\mathrm{Si}$ の添加により大幅に

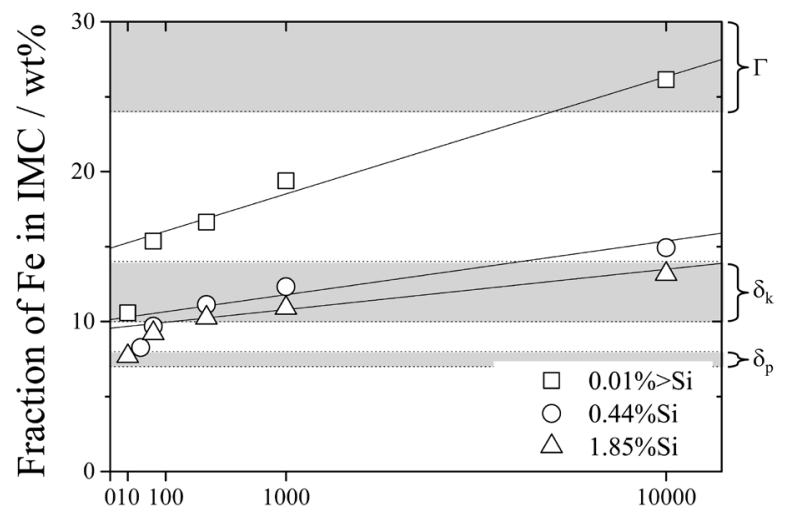

Isothermal holding time, $\mathrm{t}^{1 / 2} / \mathrm{s}^{1 / 2}$

Fig. 6. Mass fraction of Fe in F-Zn IMC layers.
低下することが分かる。この $\mathrm{Fe}$ の供給速度の低下は， $\delta_{\mathrm{k}}$ 相 鋼側に存在する $\mathrm{Fe}$ 濃度勾配が $\mathrm{Si}$ の添加により大幅に低下 することともよく対応している。以上の結果より, 本実験 における IMC 層は以下の過程で形成されると考えられる。 (1)純亜鉛篞が融点に達すると, Feが溶融亜鉛に急激に溶出 する。(2)液相中の Fe濃度が高くなるとら扎よび $\delta$ 相が出現 して液相が消滅し, その直後に旧液相領域全体に $\delta_{\mathrm{p}}$ 相およ び $\delta_{k}$ 相からなるIMC層が形成される。(3)形成された IMC 層へ $\mathrm{Fe}$ が拡散律速で供給されることで， $\delta_{\mathrm{k}}$ 相および $\Gamma$ 相 が形成・成長する。しかし, Si を添加した鋼ではIMC層形 成後の $\mathrm{Fe}$ の供給が大幅に抑制され, 鋼界面における 形成が抑制され， $\delta_{k}$ 相の成長速度が低下する。

\section{$3 \cdot 2$ 考察}

鋼への $\mathrm{Si}$ の添加が $\Gamma$ 相の形成を抑制し, $\delta_{k}$ 相の成長速 度を低下させるメカニズムを明らかにするため, 等温保持 $10^{4}$ 後の鋼界面近傍の組織を詳細に調査した。Fig.7に, 0.01 $\mathrm{wt} \%>\mathrm{Si}$ 鋼と $1.85 \mathrm{wt} \% \mathrm{Si}$ 鋼の鋼/ IMC 界面近傍組織の比較, ならびに鋼／IMC界面近傍 $\mathrm{Si}$ の濃度プロファイルを示す。 鋼への $\mathrm{Si}$ 添加により, 鋼/ IMC 界面には縞状に微細な組織 が形成していることがわかる。EBSP解析の結果, 鋼/IMC 界面に形成されたこの微細な組織はbcc構造を有してお り，その結晶方位は母相である鋼とほぼ同じであることが

a)

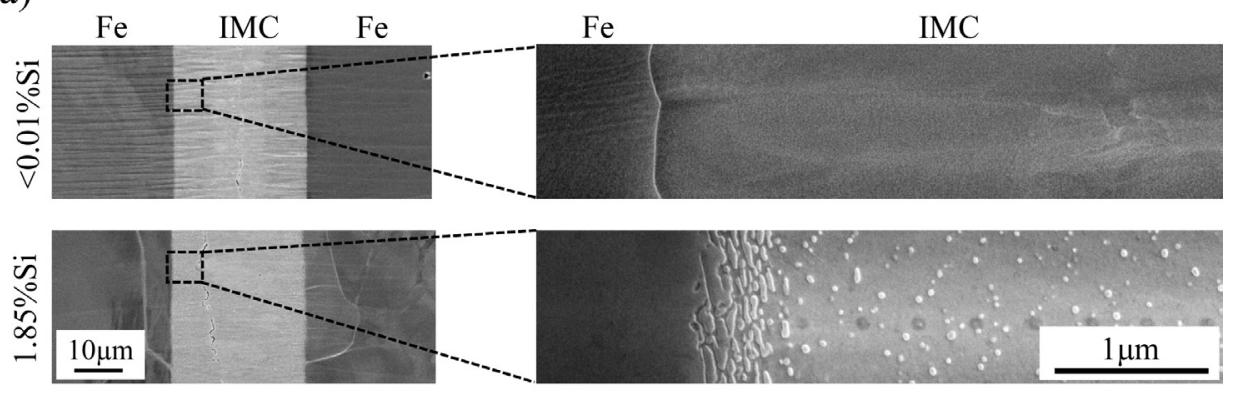

b)
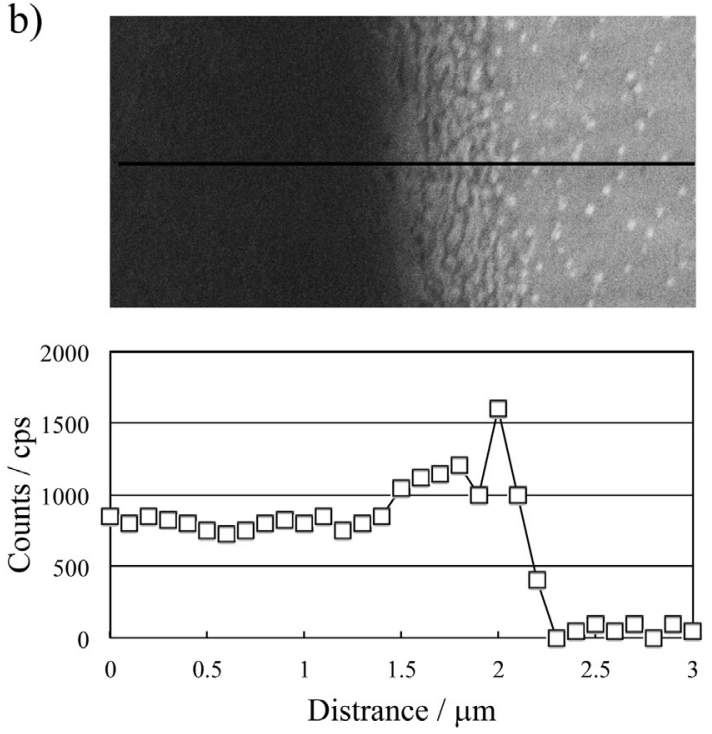

Fig. 7. (a) Difference in microstructure at the $\alpha$-Fe/IMC interface between $0.01 \mathrm{wt} \%>\mathrm{Si}$ and $1.85 \mathrm{wt} \% \mathrm{Si}$ (b) accumulation of $\mathrm{Si}$ in $\alpha$-Fe at the $\alpha-\mathrm{Fe} / \mathrm{IMC}$ interface. 
分かる。また組成解析の結果から，この bcc 構造を有する 組織にはSiが濃化していることが分かる。Fe-Si二元系状 態図ではbcc構造を有する相はフェライト $(\alpha)$ 相のみで あることから, 鋼/IMC界面に形成された微細な組織は $\mathrm{Si}$ が濃化した $\alpha-\mathrm{Fe}$ であると考えられた。一方で, 界面近傍 に形成した $\delta_{\mathrm{k}}$ 相中の Si は殆ど検出できないこともわかる。

以上の結果より, Si 添加による $\delta_{\mathrm{k}}$ 相の成長速度の低下 は, 以下のメカニズムによると考えられる。まず, 溶融亜 鉛中に $\delta_{\mathrm{p}}$ 相と $\delta_{\mathrm{k}}$ 相が形成された後, 時間経過に伴い鋼か ら Feが IMC層に供給されることで, 鋼 / IMC界面が鋼側 に移動すると同時に， $\delta_{\mathrm{k}}$ 相が成長し， $\delta_{\mathrm{p}}$ 相が減少する。し かし，この過程で $\mathrm{Si}$ は $\delta_{\mathrm{k}}$ 相には殆ど分配されず，主に鋼／ IMC 界面近傍の鋼に濃化する。その結果, 更に Feを IMC 層 に供給し $\delta_{\mathrm{k}}$ 相を成長させるには, 界面近傍に濃化した Si が 鋼中を拡散することで界面近傍の Si濃度を減少させる必 要がある。しかし, $450{ }^{\circ} \mathrm{C}$ と言う温度域では鋼中 $\mathrm{Si}$ の拡散 は $\mathrm{D}=4.8 \times 10^{-21} \mathrm{~m}^{2} / \mathrm{s}$ 程度と極めて遅い。そのため, $\mathrm{Fe} の$ 供給速度は $\mathrm{Si}$ の鋼中の拡散に律速され, 結果として $\delta_{\mathrm{k}}$ 相 の形成速度が抑制されたものと考えられる。

Fig. 8 に $450^{\circ} \mathrm{C}$ における $\mathrm{Fe}-\mathrm{Zn}-\mathrm{Si}$ 三元系計算状態図 ${ }^{4)}$ を示 す。なお，ここでは $\delta_{\mathrm{p}}$ 相と $\delta_{\mathrm{k}}$ 相を同一の $\delta$ 相として扱って いる。ここでは, $1.85 \mathrm{wt} \% \mathrm{Si}$ 鋼を例にとって考察する。ま ず, Fig. 8 中に示される $1.85 \mathrm{wt} \% \mathrm{Si}$ 鋼と純亜鉛を結ぶ点線が $\delta$ 相の安定領域を横切ることから, $1.85 \mathrm{wt} \% \mathrm{Si}$ 鋼が純亜鉛 に溶出した後に最初に形成される $\delta$ 相の平均組成は, 点線 上のいずれかの化学組成になると考えられる。その後， 相には $1.85 \mathrm{wt} \% \mathrm{Si}$ 鋼との界面を通して Feと Siが供給され る。前述の様に $\delta$ 相への Si 固溶量は本実験で用いた EDS 解 析の検出限界を下回っているため (Fig.7b), 実際の界面で の化学組成は不明ではあるが, 鋼との界面では化学組成は 大凡Fig.8中の黒点で示す化学組成に最終的には達すると 考えられる。その後の $\mathrm{Fe} の \delta$ 相への供給は, 前述の様に拡

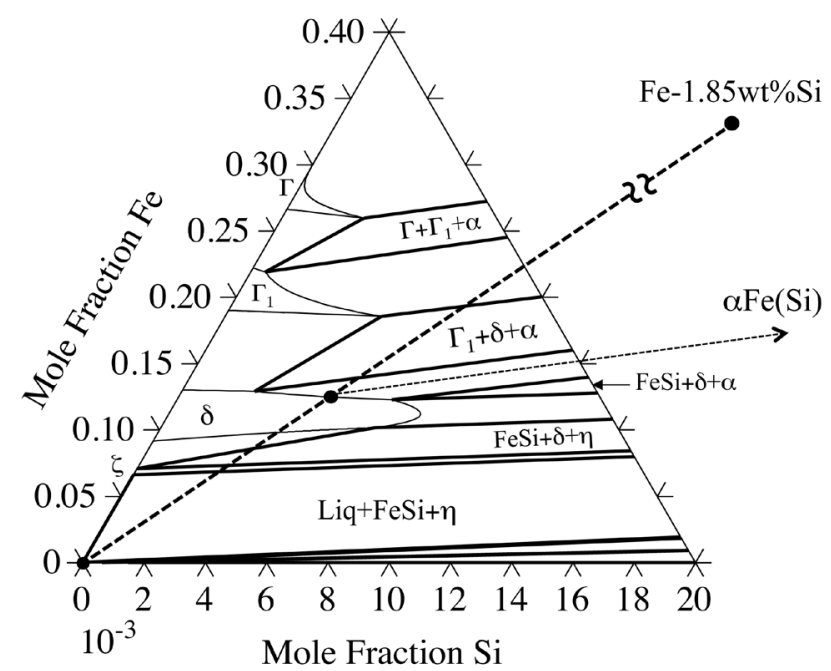

Fig. 8. Zn-rich corner of Fe-Si-Zn ternary phase diagram at $450^{\circ} \mathrm{C}$.
散律速で進行することから， $\alpha$ 相 $/ \delta$ 相界面では局所平衡 が成り立つと考えられる。このとき， $\alpha$ 相と $\delta$ 相を結ぶタ イラインの勾配は平均組成を示す点線の公配よりも大きい ため, Si は主に鋼側に分配され, $\alpha$ 相 $/ \delta$ 相界面の $\alpha$ 相側 に濃化することが分かり，観察結果を良く説明している。 また，この点近傍の $\alpha$ 相と $\delta$ 相を結ぶタイラインは $\Gamma$ 相や $\Gamma_{1}$ 相が安定となる領域は通過しないため, 界面において新 たに $\Gamma$ 相や $\Gamma_{1}$ 相が形成される可能性も低いことも理解で きる。なお, 鋼中 Si 濃度と $\Gamma$ 相や $\Gamma_{1}$ 相の安定性に関する定 量的な議論には， $\delta$ 相中の $\mathrm{Si}$ のモビリティに関する詳細な データが不可欠であり, 今後の研究課題と考えられる。

\section{$3 \cdot 3$ 単相皮膜の破壊勒性と曲げ剥離特性}

以上のように, Si 添加した鋼試料では，初期に形成さ れる Fe-Zn系IMC層は $\delta_{\mathrm{p}}$ 相主体の組織, 長時間の等温保 持により最終的には $\delta_{\mathrm{k}}$ 相単相組織となることが明らかに なった。そこでここでは, $0.01 \mathrm{wt} \%>\mathrm{Si}$ 鋼および $1.85 \mathrm{wt} \% \mathrm{Si}$ 鋼を用いて $\Gamma$ 相， $\delta_{\mathrm{k}}$ 相， $\delta_{\mathrm{p}}$ 相それぞれが主体となる Fe-Zn 系IMC皮膜を作製し, それら破壊勒性ならびに曲げ剥離 特性の評価を行った。破壊勒性の評価手法は, 前報 ${ }^{3)}$ と同 様にKyokutaらにより提案された評価手法 ${ }^{12)}$ を用いた。本 実験により得られた表面にIMC 皮膜を形成させた鋼基板 に一軸方向に引張変形を与えることで, IMC皮膜には引張 方向と垂直に何本もの平行なき裂が発生する。このとき, $\mathrm{IMC}$ 皮膜が単層の皮膜の場合には, IMC皮膜の破壊勒性值 $\Gamma$ とき裂の平均間隔 $\lambda_{\mathrm{c}}, \mathrm{IMC}$ 皮膜の層厚 $\mathrm{h}$ の間には, 以下 の等式が成り立つことが示されている ${ }^{12)}$ :

$$
\lambda_{c}=2\left(\frac{9 E \Gamma h^{2}}{\sigma_{Y}^{2}}\right)^{1 / 3}
$$

ここで, $\mathrm{E}$ は IMC皮膜のヤング率， $\sigma_{\mathrm{y}}$ は基板の有効降伏応 力である。つまり, IMC皮膜に発生したき裂の平均間隔 $\lambda_{\mathrm{c}}$ とその時の IMC皮膜の層厚 $\mathrm{h}$ を計測することで, $\mathrm{IMC}$ 皮膜 の破壊勒性值 $\Gamma$ が求まることになる。本実験では, 前報 ${ }^{3)}$ と同様にき裂間隔 $\lambda$ と IMC 皮膜の層厚 $\mathrm{h}$ は, 写真中に含ま れるき裂の総計が 50 本以上になる様に同一試料から無作 為に複数枚の断面 SEM写真を取得し, その中での平均值 を用いた。また, 破壊勒性值 $\mathrm{K}_{\mathrm{IC}}$ は $K_{I C}=\sqrt{\mathrm{E} \Gamma}$ として推定し た。曲げ剥離特性の評価では, IMC皮膜を形成させた鋼試 料に対しU字曲げ試験を行い, 圧縮応力が生じる部位にお ける IMC 皮膜の剥離状況を SEM 観察で調查した。Fig.9に, $450{ }^{\circ} \mathrm{C}$ で作製した $\Gamma$ 相， $\delta_{\mathrm{k}}$ 相， $\delta_{\mathrm{p}}$ 相の破壊勒性值を示す。 $\delta_{\mathrm{k}}$ 相の破壊勒性は前報 ${ }^{3)}$ で推定された通り， $\delta_{\mathrm{p}}$ 相よりも低 く, Г相と同等の值を示すことが確認された。また, 本実 験で得られた $\delta_{\mathrm{p}}$ 相の破壊勒性值は, $\mathrm{Si}$ の添加のない試料で 得られた前報 ${ }^{3)}$ で報告した破壊勒性值とほぼ同等の值を示

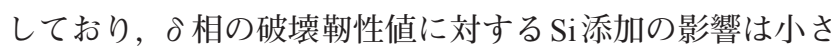
いと考えられる。Fig.10には, 曲げ試験後のそれぞれの皮 膜に生じた欠陥の様子を示す。破壊勒性のより低い「相と 


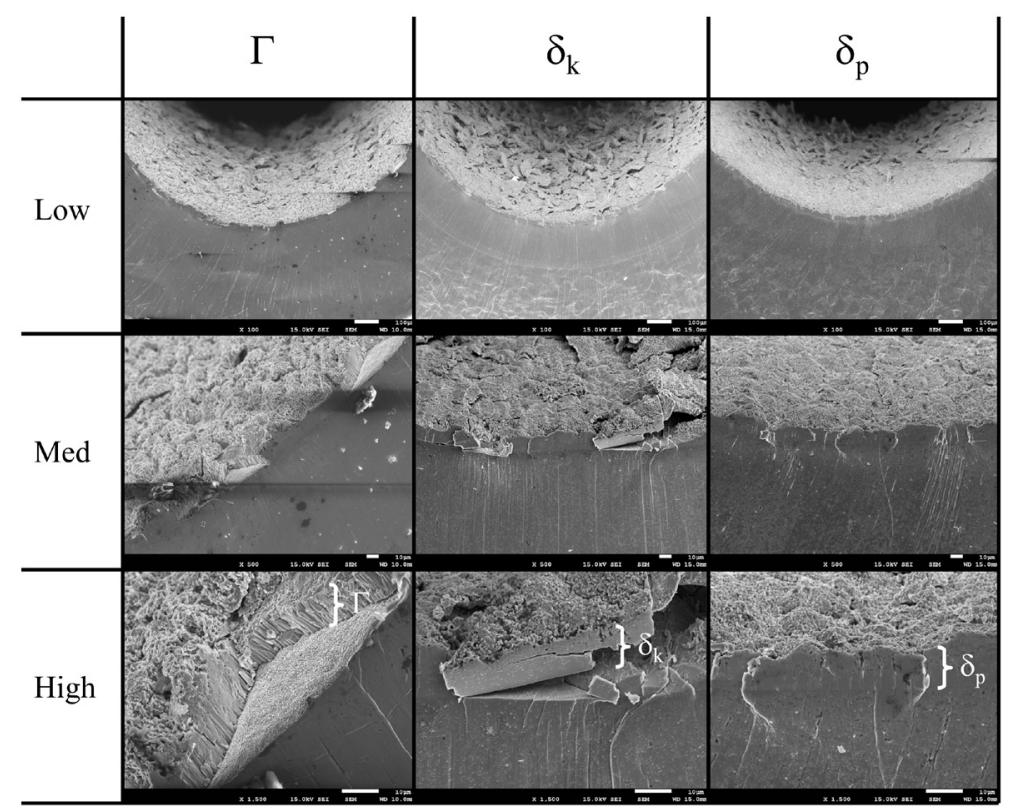

Fig. 10. Delamination of IMC layers composed mainly of either $\Gamma$ (left), $\delta_{\mathrm{k}}$ (center), or $\delta_{\mathrm{p}}$ (right) after bending the steel substrates.

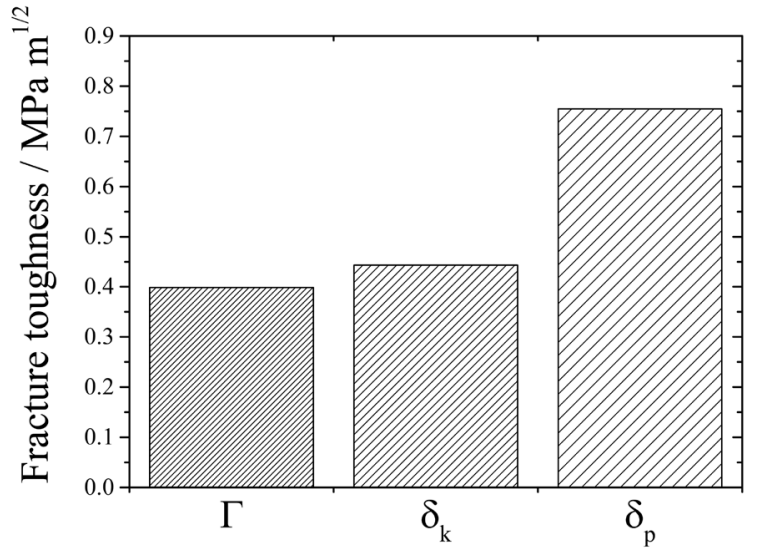

Fig. 9. Fracture toughness of $\Gamma, \delta_{\mathrm{k}}$, and $\delta_{\mathrm{p}}$ phases estimated by the method applied in the previous paper ${ }^{3}$.

$\delta_{\mathrm{k}}$ 相中には多数の直線的なき裂が生じており, 皮膜の剥離 も多数見られる。一方で， $\delta_{\mathrm{p}}$ 相の皮膜では，板厚方向に湾 曲したき裂が見られるものの, 皮膜の剥離には至っていな いことが確認された。

\section{4. まとめ}

$\mathrm{Si}$ 添加をした鋼中に純带鉛䇴を封入し $450{ }^{\circ} \mathrm{C}$ で等温保持 試験を行い，等温保持過程で鋼／溶融亜鉛界面に形成する $\mathrm{Fe}-\mathrm{Zn}$ 系IMCの形成過程を調査することで，以下の知見を 得た：

1. Siを添加していない鋼では，まず鋼界面から順に 相， $\delta_{\mathrm{k}}$ 相， $\delta_{\mathrm{p}}$ 相で構成される3つの層が形成される。その 後, 時間の経過に伴い $\delta_{\mathrm{k}}$ 相と $\Gamma$ 相が成長し $\delta_{\mathrm{p}}$ 相を侵食, 最 終的には $\Gamma$ 相単相組織へと変化する。
2. 鋼への Si添加は, 鋼/ IMC界面における を抑制すると同時に， $\delta_{\mathrm{k}}$ 相の成長も抑制する。

3. $\mathrm{Si}$ を添加した鋼では, 鋼 $/ \delta_{\mathrm{k}}$ 相界面の鋼側に $\mathrm{Si}$ が濃 化しており, 鋼から IMC層へ Feが供給される過程で $\mathrm{Si}$ が 鋼に分配される。これにより，Г相の形成が抑制されると 同時に, IMCへの $\mathrm{Fe}$ の供給速度が低下し， $\delta_{\mathrm{k}}$ 相の成長が抑 制されたと考えられた。

4. 鋼への $\mathrm{Si}$ 添加により, IMC皮膜中の $\Gamma$ 相の形成およ び $\delta_{\mathrm{k}}$ 相の成長が抑制でき, $\delta_{\mathrm{p}}$ 相主体の皮膜が形成可能で あることが示された。また， $\delta_{\mathrm{p}}$ 相主体の皮膜は，「相主体， $\delta_{\mathrm{k}}$ 相主体の皮膜と比較し曲げ剥離特性に優れることが示 された。

\section{文献}

1 ) B.P.Burton and P.Perrot: Phase Diagrams of Binary Iron Alloys, ed. by H.Okamoto, ASM International, Materials Park, Ohio, (1993), 459.

2 ) M.H.Hong and H.Saka: Scr. Mater, 36(1997), 1423.

3 ) J.Inoue, S.Miwa and T.Koseki: Tetsu-to-Hagané, submitted.

4 ) C.Sha, S.Liu, Y.Du, H.Xu, L.Zhang and Y.Liu: CALPHAD, 34(2010) 405.

5 ) R.W.Sandelin: Wire and Wire Products, 15(1940), 655.

6 ) D.C.Pearce: Proc. Semi. on Galvanizing of Silicon Containing Steels, International Lead and Zinc Research Organization, (1975), 32.

7 ) D.Horstmann: Proc. Semi. on Galvanizing of Silicon Containing Steels, International Lead and Zinc Research Organization, (1975), 78.

8 ) J.Sedzimir and H.Szymanke: Neue Hutte, 14(1969), 176.

9 ) M.A.Ghoniem and K.Lohberg: Metallurgy, 10(1972), 1026.

10) C.E.Jordan and A.R.Marder: J. Mater Sci., 32(1997), 5593.

11) R.Kainuma and K.Ishida: Tetsu-to-Hagané, 91(2005), 349.

12) N.Kyokuta, M.Koba, S.Nambu, J.Inoue and T.Koseki: J. Jpn. Inst. Met., 76(2012), 272. 